\title{
MEMBANGUN JIWA ENTREPREUNEUR MELALUI PELATIHAN PEMBUATAN KRIM TABIR SURYA KENCUR
}

\author{
Linga Ikaditya ${ }^{1}$, Irvan Herdiana ${ }^{2}$, Lulu Setiyabudi ${ }^{3}$ \\ ${ }^{112) 33}$ Program Studi DIII Farmasi Poltekkes Kemenkes Tasikmalaya
}

lingga.ikaditya@gmail.com

Diterima: 30 Oktober 2018

Direvisi: 06 November 2018

Diterbitkan:07 Januari 2019

\begin{abstract}
Kahuripan Village, Tasikmalaya City is an area that is one sub-district with the Tasikmalaya Ministry of Health Poltekkes. The choice of this location is an effort to provide maximum benefit for the community around the campus. The partner problems identified were the existence of community groups which were active cadres of Kahuripan village which were not economically productive. The method used is by providing assistance to the community through technology transfer through counseling and demonstration. The target audience of the Community Partnership-based Community Service Program is the Kahuripan Village Community, which is an economically unproductive community and 10 active Kelurahan cadres are divided into 2 groups. The results obtained from community service activities were, increased cadre knowledge about entrepreneurship, the establishment of commitment and leadership of each group through the team building method, increased cadre knowledge in making Tabir Surya cream products from raw materials and increased cadre information related to financing efforts venture capital.
\end{abstract}

Keywords: Community Service Program, Sunscreen cream, Kaempfreria galanga

\begin{abstract}
ABSTRAK
Kelurahan Kahuripan Kota Tasikmalaya merupakan suatu wilayah yang satu Kecamatan dengan Poltekkes Kemenkes Tasikmalaya. Pemilihan lokasi ini adalah upaya untuk memberikan manfaat sebesar-besarnya untuk masyarakat disekitar kampus. Permasalahan mitra yang teridentifikasi adalah adanya kelompok masyarakat yang merupakan kader aktif kelurahan Kahuripan yang tidak produktif secara ekonomi. Metode yang digunakan yaitu dengan melakukan pendampingan kepada masyarakat melalui transfer teknologi melaui penyuluhan serta demonstrasi. Khalayak sasaran dari Program Pengabdian Masyarakat berbasis Kemitraan Masyarakat ini adalah Masyarakat Kelurahan Kahuripan, yang merupakan masyarakat tidak produktif secara ekonomis dan kader aktif Kelurahan sebanyak 10 orang yang dibagi kedalam 2 kelompok. Hasil yang diperoleh dari kegiatan pengabdian masyarakat adalah, peningkatan pengetahuan kader mengenai wirausaha, terbangunnya komitmen dan leadership masing-masing kelompok melalui metode team building, meningkatnya pengetahuan kader dalam membuat produk krim Tabir Surya dari bahan baku kencur dan peningkatan informasi kader terkait usaha-usaha mendapatkan pembiayaan modal usaha.
\end{abstract}

Kata kunci : Pengabdian Masyarakat, Krim Tabir Surya, Kencur 


\section{PENDAHULUAN}

Kelurahan Kahuripan kami pilih sebagai tempat kegiatan ini karena merupakan salah satu kelurahan yang banyak mendapatkan bantuan PKH (Program Keluarga Harapan). PKH merupakan suatu program penanggulangan kemiskinan dan meningkatkan kualitas sumber daya manusia terutama pada kelompok masyarakat miskin. Fokus utama program ini adalah pada bidang pendidikan dan kesehatan (Budiman, 2016). Banyaknya jumlah penerima PKH ini menjadi salah satu indikator belum adanya kemandirian ekonomi keluarga yang dapat menanggulangi kemiskinan dan peningkatan kualitas sumber daya manusia. Sehingga kami berharap dengan adanya kegiatan Progran Kemitraan Masyarakat (PKM) ini dapat menurunkan angka penerima PKH secara khusus dan dapat meningkatkan taraf ekonomi masyarakat Kelurahan Kahuripan pada umumnya. Diperlukan adanya berbagai program yang dapat dilakukan dalam rangka peningkatan kesejahteraan keluarga dengan memanfaatkan dan mengelola lingkungan sekitarnya (Hastuti, 2014). Salah satu program yang dapat dilaksanakan oleh masyarakat dalam upaya peningkatan kesejahteraan keluarga, khususnya di bidang kesehatan adalah program penanaman dan pemanfaatan Tanaman Obat Keluarga (TOGA) (Liya dan Farid, 2015).

Pengabdian Masyarakat di Kelurahan ini sudah dilakukan 2 tahun berturut-turut dengan rincian kegiatan yaitu pada tahun pertama dilakukan budidaya tanaman kencur dan tahun kedua pembuatan beras kencur instan. program yang dilakukan adalah dengan pembekalan keterampilan, pemberian bibit tanaman untuk budidaya serta fasilitas alat untuk produksi beras kencur instan. Sebagai alternatif pengembangan diversifikasi produk kencur, maka pada pengabdian masyarakat tahun ini diarahkan pada pembuatan produk kencur yang memiliki prospek bisnis. Alternatif solusi lainnya adalah penyuluhan manajemen usaha dengan memberikan pengetahuan bagi masyarakat tentang kewirausahaan sehingga dapat menumbuhkan jiwa entrepreneurship. Jenis produk yang akan dikembangkan adalah membuat Tabir Surya yang berbahan baku dari kencur. Minyak kencur (Oleum Kaempferiae Galangae Rhizomae) memiliki aktivitas fotoprotektor dan antioksidan karena adanya senyawa ethyl-pmethoxycinnamate dan ethyl cinnamate. Untuk melindungi bahaya yang disebabkan oleh radiasi matahari pada kulit, salah satunya dapat digunakan kosmetik tabir surya (krim tabir surya) ((Nole dan Johnson, 2004; Adhami dkk., 2008; dan Wright dkk., 2012).

\section{METODE}

Penyelenggaraan penyuluhan dan pelatihan tentang cara produksi krim krim tabir surya kencur dilakukan secara partisipatif masyarakat yang mengikuti penyuluhan dilibatkan secara aktif dan efektif dalam merubah perilaku. Menayangkan video tentang proses pembuatan produk untuk memotivasi masyarakat melaksanakan kegiatan produksi kencur sebagai produk komersial.

Sasaran peserta penyuluhan adalah seluruh masyarakat Kelurahan Kahuripan Kecamatan Tawang Kota Tasikmalaya. Kegiatan ini diharapkan dapat meningkatkan ketahanan ekonomi masyarakat khususnya Tawang melalui produksi krim tabir surya kencur. Jumlah peserta pelatihan sekitar 10 orang terdiri atas kader aktif Kelurahan. 
Dalam hal ini pihak Kelurahan Kahuripan Kota Tasikmalaya sebagai pihak yang mempunyai wilayah dimana kegiatan ini hendak dilakukan, memberi dukungan dalam kegiatan ini dengan menyediakan tempat pelatihan. Selain itu pihak Kelurahan Kahuripan, Tokoh Masyarakat di Kelurahan Kahuripan, Dinas Perindustrian Kota Tasikmalaya, Dinas Kesehatan Kota Tasikmalaya, serta Puskesmas Kahuripan diharapkan akan dapat memberikan dukungan melalui program yang terkait dengan pemberdayaan masyarakat melalui produksi produk komersial dari tanaman obat.

Dalam rangka mencapai tujuan maka ditempuh langkah-langkah sebagai berikut: menghubungi Camat Tawang dan Lurah Kelurahan Kahuripan untuk perizinan kegiatan pengabdian masyarakat di wilayah kerja Kelurahan Kahuripan, menghubungi Dinas Kesehatan Kota Tasikmalaya, Dinas Perindustrian dan Perdagangan serta Puskesmas Kahuripan untuk koordinasi lintas sektor, menyelenggarakan penyuluhan dan pelatihan dengan materi: membangun jiwa kewirausahaan, keamanan produk kosmetik, produksi krim krim tabir surya kencur dan informasi pemodalan. Adapun waktu yang digunakan pada bulan April - Oktober 2018 di Kelurahan Kahuripan Kecamatan Tawang Kota Tasikmalaya. Alatalat penunjang dalam kegiatan ini meliputi LCD, Materi Penyuluhan \& Pelatihan, ATK, Laptop dan alat peraga dalam produksi.

Sumber daya manusia yang terlibat dalam kegiatan ini adalah Dosen yang memiliki kepakaran untuk menyelesaikan persoalan mitra dan mahasiswa yang membantu aspek teknis. Tim pelaksana kegiatan ini terdiri dari Dosen yang memiliki kemampuan dan kepakaran sesuai dengan uraian tugas dan kewajibannya.

\section{HASIL DAN PEMBAHASAN}

Kegiatan dan hasil pelaksanaan Program pengabdian masyarakat melalui pembinaan masyarakat dalam pembuatan Tabir Surya kencur sebagai Upaya Peningkatan Kemandirian Ekonomi Keluarga di Keluruhan Kahuripan ini ditujukan untuk mendapatkan luaran yang diharapkan dengan menyelesaikan permasalahan yang ditemukan di Kelurahan tersebut. Khalayak sasaran dalam kegiatan ini adalah kader aktif di kelurahan tersebut. Pemilihan tersebut didasari karena diharapkan dengan mengikutsertakan kader aktif dapat lebih mengoptimalkan keberhasilan kegiatan.

\section{Membangun komitmen kelompok}

Dalam hal mewujudkan komitmen kelompok dilakukan dengan tim building melalui permainan. Dalam setiap permainan tersebut ada makna yang terkandung diantaranya menjalin kekompakkan untuk membangun kerja sama tim dalam menyelesaikan tantangan, belajar bertanggung jawab pada tugas masing-masing, rela berkorban untuk tercapainya tujuan bersama, belajar memimpin, berinteraksi, serta menyamakan pandangan. Menurut Wibawa (2014), Berkembang tidaknya suatu organisasi sangat dipengaruhi adanya kepedulian dan kualitas SDM dalam menggerakkan organisasi. Dengan demikian, proses peningkatan kapasitas (capacity building) dan pembangunan karakter (caracter building) SDM menjadi hal yang mutlak dilakukan.

Melalui permainan ini terbentuk 2 kelompok kader dimana masing-masing kelompok terdiri dari 5 orang. Dalam usaha pembentukan kelompok ini, masingmasing kelompok diminta untuk memilih ketua kelompok yang dianggap kredibel untuk memimpin kelompok tersebut. Setelah terbentuk ketua kelompok akan 
ditindaklanjuti dengan penyusunan struktur organisasi kelompok. Bagian-bagian dalam struktur organisasi akan disesuikan dengan kebutuhan kelompok masing-masing.

2. Koodinasi lintas sektor

Kordinasi lintas sektor dilakukan dalam rangka optimalisasi kegiatan sehingga diharapkan adanya kontribusi dari segala aspek.

3. Informasi pemodalan

Informasi Pemodalan dilakukan melalui pemaparan informasi terkait Pelaksanaan Bantuan Pemerintah Bagi Wirausaha Pemula dan perizinan IUMK (Izin Usaha Mikro Kecil) oleh Kasie. Usaha Mikro Dinas Koperasi UMKM, Perindag Kota Tasikmalaya. Dalam Kegiatan ini didapatkan beberapa informasi diantaranya Bantuan Pemerintah Bagi Wirausaha Pemula diperuntukan untuk yang berusia dibawah 45 tahun dengan mengajuka proposal kegiatan usaha ke Kementerian Koperasi dan UKM. Sementara, untuk kader yang terlibat dalam kegiatan didominasi dengan umur diatas 45 tahun. Namun, perlu diidentifikasi ulang terkait usia kader atau alternatif dalam melakukan akses pembiayaan melalui Kementerian Koperasi dan UKM. Informasi lain yang didapat adalah terkait IUMK (Izin Usaha Mikro Kecil) yang perlu ditempuh untuk : mendapatkan kepastian dan perlindungan dalam berusaha dilokasi yang telah ditetapkan; mendapatkan pendampingan untuk pengembangan usaha; mendapatkan kemudahan dalam akses pembiayaan ke lembaga keuangan bank dan non-bank; dan mendapatkan kemudahan dalam pemberdayaan dari pemerintah, pemerintah daerah dan/atau lembaga lainnya.

4. Penyuluhan

Proses penyuluhan dalam rangka transfer knowledge. Jadwal penyuluhan disesuaikan dengan jadwal kader dan narasumber sehingga kehadiran kader $100 \%$. Tahap awal kegiatan dilakukan dengan melakukan pretes. Kegiatan ini dilakukan untuk melihat pemahaman awal kader sebelum dilakukan kegiatan. Berdasarkan hasil pretes didapatkan hasil yaitu rata-rata tingkat pengetahuan warga terkait materi penyuluhan adalah pada kategori baik yaitu $56 \%$. Kategori tersebut sesuai dengan Notoatmodjo (2003) dimana tingkat pengetahuan sangat baik 76-100\%, pengetahuan baik $51-75 \%$, pengetahuan cukup baik $26-50 \%$ dan pengetahuan tidak baik 0-25\%.

Materi penyuluhan yang diberikan yaitu membangun usaha, keamanan produk kosmetik dan perizinan produk kosmetik, dan pemaparan pembuatan produk. Kegiatan ini diharapkan dapat meningkatkan motivasi kader dalam upaya membangun bisnis, mengetahui perbedaan pedagang dan wirausaha, mengembangkan strategi pemasaran produk, mengembangkan produk yang aman untuk dipasarkan, mengetahui tata cara perizinan produk dan dapat melakukan sendiri pembuatan produk krim kencur.

Tahap terakhir dalam kegiatan penyuluhan adalah dilakukan postes untuk evaluasi keberhasilan program terkait pemahaman kader terhadap transfer knowledge yang dilakukan. Berdasarkan hasil postes didapatkan nilai rata-rata tingkat pengetahuan yaitu $71,3 \%$. Nilai tersebut menunjukkan bahwa berdasarkan kategori tingkat pengetahuan menurut Notoatmodjo (2003) bahawa kategori tingkat pengetahuan kader pada kategori baik dalam menerima transfer knowledge yang dilakukan oleh narasumber. Dari hasil tersebut dapat dilihat pada tabel 1.1. bahwa kategori tingkat pengetahuan sebelum dilakukan penyuluhan dan setelah dilakukan penyuluhan pada kategori tingkat pengetahuan baik sebelum dilakukan kegiatan 
maupun setelah dilakukan kegiatan tetapi secara kuantifikasi nilai mengalami peningkatan.

Tabel. 1.1 Indikator Tingkat Pengetahuan Kader

\begin{tabular}{ccc}
\hline Indikator & Sebelum Penyuluhan & Setelah Penyuluhan \\
\hline $\begin{array}{c}\text { Rata-rata tingkat } \\
\text { Pengetahuan } \\
\begin{array}{c}\text { Kategori Tingkat } \\
\text { Pengetahuan }\end{array}\end{array}$ & 56 & 71,3 \\
\hline
\end{tabular}

5. Praktek produksi

Pembuatan produk dilakukan dengan metode praktek langsung. Setiap kelompok diberikan alat dan bahan yang digunanak dalam membuat krim kencur. Bahan yang digunakan adalah basis krim, kencur, aquades, dan oleum lavender. Sedangkan alat yang digunakan adalah blender, penyaring, beaker glass, mortir dan stemper, spatula dan pot krim $10 \mathrm{~g}$. Basis krim dipilih yang sudah siap pakai untuk memudahkan masyarakat dalam membuat sendiri di Rumah dan mempercepat proses pembuatan. Hasil pembuatan produk dimasukkan ke dalam pot krim yang sudah disiapkan.

6. Monev

Monev dilakukan untuk melihat keberhasilan produk yang dibuat. Berdasarkan hasil monev sediaan produk memiliki stabilitas yang baik dan tidak terlihat tandatanda kerusakan produk krim.

Berdasarkan hasil kegiatan bahwa adanya respon positif dari berbagai pihak yang terlibat dalam kegiatan ini sebagai kekuatan untuk melakukan kerjasama lebih intensif agar dapat didukung dalam segala aspek, sehingga diharapkan akan tumbuh wirausaha baru. Implementasi kerjasama lintas sektor akan diwujudkan dalam perencanaan pengabdian masyarakat tahun 2019. Rencana Tindak Lanjut yang akan dilakukan adalah sebagai berikut : mengevaluasi produk yang akan dikembangkan sebagai unit bisnis dan memilih produk yang akan dipasarkan, koordinasi ke seluruh stakeholder terkait kelanjutan program agar terbangun wirausaha baru, melakukan penjajagan kemungkinan keterlibatan pihak pemerintahan dalam hal ini walikota Kota Tasikmalaya dalam memberikan kontribusi kebijakan produk yang dibuat menjadi produk khas yang dihadirkan dalam kudapan rapat/pameran seni budaya dll dan mendaftarkan HAKI untuk produk yang telah dibuat.

\section{SIMPULAN}

Adanya pengabdian kepada masyarakat tahun anggaran 2018 untuk kader kelurahan Kahuripan Kota Tasikmalaya menghasilkan : peningkatan pengetahuan kader mengenai wirausaha, terbangunnya komitmen dan leadership masing-masing kelompok melalui metode team building, meningkatnya pengetahuan kader dalam membuat produk krim Tabir Surya dari bahan baku kencur, peningkatan informasi kader terkait usaha-usaha mendapatkan pembiayaan modal usaha.

\section{DAFTAR PUSTAKA}


[1.] Adhami, V. M., Syed, D. N., Khan, N., and Afad, F., 2008, Phytochemicals for Prevention of Solar Ultraviolet Radiation-Induced Damages, Photochem. Photobiol., $84,489-500$

[2.] Budiman, A., 2016, Walikota Pantau Penyaluran Dana PKH Di kantor Pos, http://setda.tasikmalaya.go.id, diakses tanggal 1 Desember 2016.

[3.] Hastuti, 2014, Pemberdayaan Ibu Rumah Tangga Di Desa Purwobinganun Kecamatan Pakem Kabupaten Sleman Dalam Penanaman Dan Pemanfaatan Tanaman Obat Keluarga. Laporan Hasil Pengabdian Masyarakat, Universitas Negeri Yogyakarta.

[4.] Liya, B. K. dan Farid, M.M, 2015, Proses Pemberdayaan Melalui Paguyuban Tanaman Obat Keluarga (Toga) Di Kelurahan Tlogoanyar Kabupaten Lamongan. Publika, Vol.3(7).

[5.] Nole, G., and Johnson, A. W., 2004, An Analysis of Cumulative Lifetime Solar Ultraviolet Radiation Exposure and The Benefits of Daily Sun Protection, Dermatol. Therapy, 17, 57-62.

[6.] Wibawa, EKa., 2014, Capacity Building Dan Strategi Peningkatan Kualitas Sdm Organisasi., http://bpsdm.kemenkumham.go.id, diakses tanggal 29 September 2018,

[7.] Wright, C.Y., Norval, M., Summers, B., Davids, L., Coetzu, G., and Oriowo, M.O., 2012, The Impact of Solar Ultraviolet Radiation on Human Heallth in Sub-Sahara Africa, $S$. Afr. J. Sci.,108 (11/12), 1-6. 